\title{
Handbook for Preparation of DOE Procurement Request Forms
}

November 1990

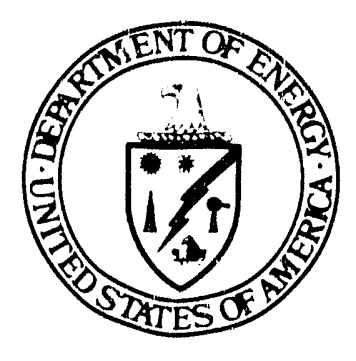

U.S. Department of Energy

Office of Procurement, Assistance and Program Management

Washington, DC 20585 
TABLE OF CONTENTS

INTRODUCT ION

\section{SECTION}

1 GENERAL INFORMATION

1.1 Requirements

1.2 Purpose of Forms

1. 3 General Instructions

1

2 DETAILED INSTRUCT IONS FOR COMPLETING DOE F 4200.33 PROCUREMENT REQUEST-AUTHOR IZATION

3 DETAILED INSTRUCT TONS FOR COMPLETING DOE F 4200.34 PROCUREMENT REQUEST - AUTHORIZATION FUNDING DATA CONT INUAT ION SHEET

4 ADD IT IONAL INSTRUCTIONS FOR PROCESS ING PROCUREMENT REQUESTS

4.1 How to Change or Correct a PR

4.2 Carryover PR Processing

4.3 Multiple PR Processing

4.4 Transfer Procedures 


\section{APPENDICES}

A. Awarding otfice Codes

B. Catalog of Federal Domestic Assistance (CFDA) Codes

C. Office of Scientific and Technical Information (OSTI)

Deliverable Codes

\section{LIST OF FIGURES}

FIGURE

PAGE

1

Procurement Request - Authorization

DOE F 4200.33

Procurement Request - Authorization

Fund ing Data Continuation Sheet

DOE F 4200.34

Following page 1

Following pase 1 
The Procurement and Ass istance Data System (PADS) provides a mechanism for collecting, assembling, organizing, and presenting acquisition and assistance data for the Department of Energy (DOE). This handbook and associated documents establish a uniform system to report acquisition/assistance data to PADS for the collection, processing, and dissemination of of ficial statistical data on the Department's acquisition and assistance actions. The data provides, based on information available at the time of request, a basis for any recurring and special reports to the senior procurement executive, Congress, General Accounting office (GAO), Federal executive agencies, office of Management and Budget (OMB), and the general public. PADS is also used to satisfy DOE's statutory reporting requirements to the office of Management Budget, Congress, and other Federal agencies. Accurate and timely collection of PR data is a key element in this reporting.

Additionally, in-process PR's are tracked by program officials to monitor the committment and obligation of their funds and to plan for the orderly conduct of program activities.

This handbook contains detailed instructions and procedures for the proper preparation of PR forms. Appendices are also provided which list the codes to be used in some of the items of data on the PR form. 
1.1 REQUIREMENTS

In accordance with the instructions set forth in DOE Order 1331.1C, dated February 17, 1989, "Procurement and Assistance Data System," program office managers shall submit completed Prourement Request forms ( $P R^{\prime} s$ ) for acquisition and assistance transactions to the appropriate awarding office. Further, awarding office managers are responsible for the collection and submission of data to PADS on the receipt/acceptance of these procurement requests.

To elaborate, a PR is required for all new assistance awards. A PR is also required tor all acquisition actions where the total award value exceeds the small purchase threshold. (A PR is optional for new acquisition awards below this amount at the awarding office's discretion.) Any funding modification to any assistance award requires a PR. Any funding modification to any acquisition award over the small purchase threshold requires a PR.

1.2 PURPOSE OF FORMS

DOE F 4200.33 Procurement Request - Authorization. This form is used by the initiating office to authorize an awarding office to execute an acquisition/assistance agreement for the acquisition of services or personal property whether from the private sector or another governmental entity, and for assistance support to private sector or another non-Federal governmental entity. An example of DOE F 4200.33 is dispiayed as figure 1 .

DOE F 4200.34 Procurement Reque: $t$ - Authorization Funding Data Continuation Sheet is only used to provide additional funding information when there is not sufficient space on the PR, DOE F 4200.33. This Continuation Sheet will not be processed alone. It must always be used as a supplement at tached to the PR, DOE F 4200.33. An example of DOE F 4200.34 is shown as figure 2. 
2. From Initialing Office

8 F irpose of Acquisition (Check as many as apply)

Supplies

Construction

ArchitecuEngineer Services

Other (Requires Description)

10. Name

10a. Division

12. Product or Service Code For Acquisition Actions Only

13. CFDA Number For Assistance Actions Only

16. OST: Deliverable For All Actions

20. Unsolicited Proposal Number

22. Government Property

Research \& Developmerit

Advisory \& Assistance

Services

Support Services

17. (Reserved)
4. Change/Correction io a PR in Plocess Yes No

5. If item 4 is YeS. Enter PR Correction Letter

6. Acquisition Assistance

7. Consistent with Principal Purpose of Program Yes I; No

9. Description of Work/Purpose of Assistance

Has List of Sources Been Altached? Yes : No

\section{Address}

Proposed Instrument: 14. Cooperative Agreement i] 15. Grant $\square$

\section{Desired Award Date}

\section{Government Share}

18. Master BIN

21. Project Number

F- Furnished, P. Purchased, B. Both, N-Not Involved

FINANCIAL DATA

24. Awardee Share

25. Total

FY FUNDS COMMITTED

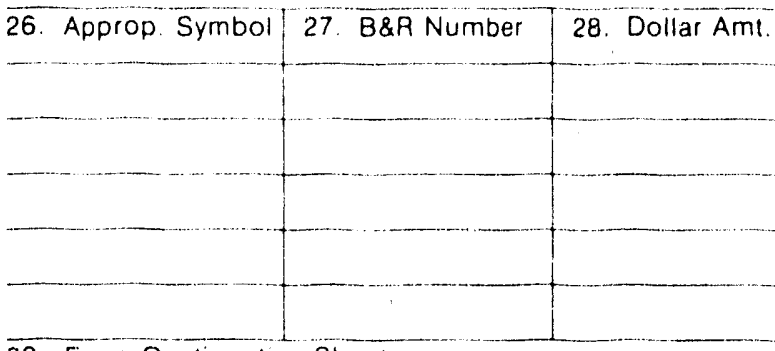

33. From Continuation Sheel

35. Total Funds This PR

Are These Annual Funds?

(i) Yes i] No

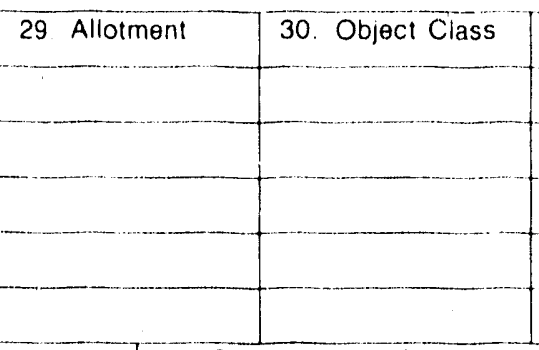

34. Project Period from

36. For Assistance Actions Only:

Budget Period fiom thru

\section{PROJECT MANAGER/INITIATOR}

37. Name
38. Signature
39. Date

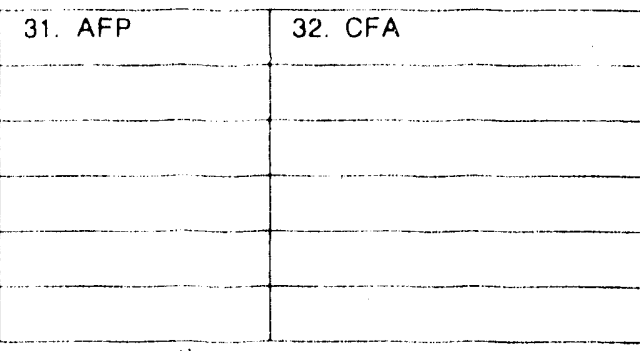

thru

\section{PROGRAM OFFICIALS}

We hereby certify that if the funds cited are Annual Funds, this is an appropriate use of the Annual Funds.

\begin{abstract}
42. Reviewing Official's Name
\end{abstract}
45. Budget Official's Name

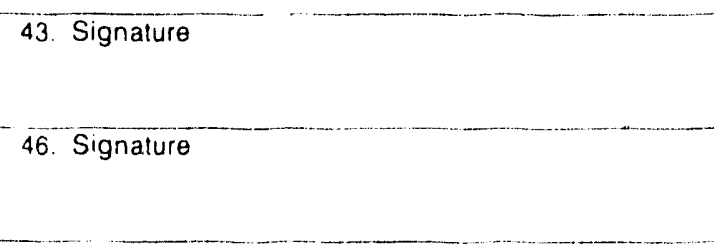

CERTIFYING OFFICIAL, I Hereby certify that the funds cited in item 35 are available
48. Name

51 Iritating Office/Local Office Use
49. Signature
40. Office Code

41. FTS Telephone Number 
1. PR Number

4 APPROPRIATION SYMBOI
2. Change/Correction to a PR in Process

$$
\text { B\&R }
$$
NUMBER

\section{Yes}

6 DOLLAR AMOUNI
No

8 OBJECT 9 AFF
CLASS
3 If ltem 2 is Yes. Enter PR Correcion Letter
10

CrA 
Many items of data on the Procurement Request form that are entered into the PAlls database have a defined field length, or an exact number of characters allowed. For example, the Product or Service Code (Item 非13) is 4 characters in length. The CFDA Number (Item 非14) is 5 digits, and Government Property (Item 非3) is one letter. Dollar fields, such as the government share (Item 非4) may conta in as few as one but no more than 9 digits. The Description of Work/Purpose of Ass istance, (Item 非9), has a maximum field length of 180 characters.

All dollar amounts must be rounded to the nearest whole dollar. PADS does not accept fractions of dollars. Parentheses () should be used to surround a negative dollar amount such as a deobligation or decommitment of funds. The dollar amounts $\$ 10,001.00$ througi: $\$ 10,001.49$ should be entered as $\$ 10,001$, and $\$ 10,001.50$ through $\$ 10,001.99$ should be entered as $\$ 10,002$. The decommitment of $\$ 10,450$ should be entered as $(\$ 10,450)$.

When entering the names of individuals, enter 1 ast name first followed by first name and middle initial. Do not include titles, i.e., Mr., Mrs., Ms., Dr., etc. A valid example is Smith John A.

Use the following format for dates: MM DD YY. For example, the date August 1, 1989, should be entered as 080189.

PADS is an unclassified data base; therefore, absolutely NO classified information may be entered in to PADS.

DOE F 4200.33 is a multicopy form. The five copies in each set are color coded and designated for distribution as follows:

Color Distribution Point

White Original for Contract File

Blue Data Entry Control Point (Procurement office)

Pink Controller

Green Initiating office

Goldenrod Small and Disadvantaged Business Utilization Of $\mathrm{fice}$

This distribution sequence was established from the suggestions of several users. It may be altered to accommodate the needs of individual field organizations. 
In addition to the codes found in the appendices of this Handbook, detailed 1 istings of all valid odes required for the completion of a $P R$ are located in the PADS Miscellaneous Tables, available through request to the PADS Hotl ine or by retrieval of PADS Standard Report 非 814 .

All coments or questions regarding the information contained in this Handbook should be directed to the office of Procurement Information Systems/Property, Prourement Information Systems and Analys is Division, PR-161, FTS 896-8267. 
2. DETAILED INSTRUCTIONS FOR COMPLETING DOE F 4200.33 PROCUREMENT REQUEST - AUTHORIZATION

ITEM IDENT IFICA'ION
To Awarding of fice
2 From Initiating Of fice

PROCEDURES

Enter the business mailing address of the procurement office to which the Procurement Request is being sent. Normally, this is the office which will process the award action, e.g., washington office of Procurement Operations, $P R-30$, Forrestal Building, wash ington, DC, 20585.

Enter the mail ing address of the office initiating the Procurement Request, e.g., Office of Building Energy Research, CE-42 Forrestal Building, washington, $D C$, 20585.

PR Number

Enter the 16-character PR number in the following format:

Sample: 01-90CE00001.000

\begin{tabular}{|c|c|}
\hline Position & Mean ing \\
\hline $1-2$ & $\begin{array}{l}\text { Awarding office Code }- \text { A } \\
\text { complete } 1 \text { ist of codes is } \\
\text { contained in Appendix A. }\end{array}$ \\
\hline 3 & '-' A dash \\
\hline $4-5$ & $\begin{array}{l}\text { Last two digits of the } \\
\text { fiscal year of the } \\
\text { anticipated award. This } \\
\text { entry must be equal to or } \\
\text { greater than the current } \\
\text { year. }\end{array}$ \\
\hline $6-7$ & $\begin{array}{l}\text { Initiating office Code - The } \\
\text { two-character code which } \\
\text { identifies the program } \\
\text { office that is initiating } \\
\text { the award. }\end{array}$ \\
\hline
\end{tabular}




\section{Position}

$8-1.2$

13

$14-16$
Meaning

Serial Number - This 5-character entry must be numeric and unique with in the initiating office identified in Position 6 and 7. If the $P R$ is for a new award, this unique number is obta ined from the register or 1 isting na intained by the initiating office identified in Posicions 6 and 7. If the PR is to modify or fund an existing award, this unique number must be the same serial number as is used in the existing award instrument number.

'. A decimal point.

Amendment Number - If the PR is for a new award, enter "000." If the PR is to modity an existing award, enter the appropriate amendment number as follows: If the PR is being prepared by a Headquarters organization, enter "001" or the rext un used sequential number up to "499" for the amendment initiated with in the fiscal year entered in Positions 4 and 5 . 


\begin{tabular}{|c|c|c|c|}
\hline ITEM & IDENT IF ICAT ION & PROCEDURE & \\
\hline & & Position & Meaning \\
\hline 3 & PR Number & $14-16$ & $\begin{array}{l}\text { If the PR is not being } \\
\text { prepared by a Headquarters } \\
\text { program of fice, enter " } 501 " \\
\text { or the next unused } \\
\text { sequential number up to } \\
\text { "999" for the amendment } \\
\text { initiated within the fiscal } \\
\text { year entered in Positions } 4 \\
\text { and 5. }\end{array}$ \\
\hline
\end{tabular}

The $t \perp r s t$ amendment issued in a new fiscal year always contains the amendment number "001" or "501" regardless of what the last used amendment number was in the previous fiscal year. The use of a different series prevents duplication of a procurement request number that might occur when two separate offices are issuing procurement requests pertaining to the same award. Awarding of fices are not required to use "501-999" series. (Additional information regarding the PR number can be found in DOE Order 1331.2, "Departmental Business Instrument Numbering System.")

4 Change/Correction to a PR in Process
Check the block marked "YES" if this is a change or correcicion to a PR which has been forwarded to Procurement and is presently in process. Sheck the block marked "NO" if this is the initial PR for either a new award or a modification to an existing award. 
If Item 4 is Yes, Enter PR Correction Letter

Acquisition/
As a istance
PROCEDURES

If this is a change or correction action as defined in Item 4, enter an alphatetic character. Start with " $A$ " and continue through the alphabet as additional changes occur.

For example, a new award would have a PR amendment numbe:" of ".000." If there were no funds on this PR, a PR submitted to add tunds prior to award would have an amendment number of ".000A."

Theck the block following ACQUISITION if inis action covers any of the following $\therefore$ at $\approx$ gories :

Basic Agreement (Terms \& Conditions Only) Blanket Purchase Agreement

Contrai: $t$

Delivery Order

Interagency Agreement (Purchase)

Basic Ordering Agreement.

Indefinite Delivery Contract

Purcinase Order

Research Opportunity Award

Special Research Contract

Task Order

Small Purchase/Small Business

Competitiveness Demonstration Program

Bonneville Intergovernmental Agreernent waste Management Revenue Collection

Internat ional Agreement

Memorandum of Understanding

Power Manage ment

Lease of Real Property

Other Real Property Transactions

Purchase of Real Property Interagency Agreement (Sales)

Sales Contract

Check the block following ASSISTANCE if this action covers any of the following categories:

Cooperative Agreement

Grani

Loan of Monies

Loan Guarantee

Loan of Property 
Cons istent with Principal Purpose of Program?

8
Produc: or Service Code

Description of work/Purpose of Ass istance

Name

Division

Address

Purpose of Acquisition

Produc: or Service
Code

\section{PROCEDURES}

Check the block marked "YES" if the type of transaction indicated in Item 6 is consistent with the principal purpose of the program under which the request originated. Check "NO" if inconsistent. Any inconsistent transaction must be explained and justified in eitrer the principal program determination or an at tachinent to the Procurement Request form. For further details, refer to $D O E$ Order 4600.1A, "rinancial Ass istance Procedures Manunl."

This 1 ist provides information to program and procurement officials on the type of work to be done. Check as many as may apply to the action being authorized.

Enter the title or brief description of the acquisition or assistance action being requestad. Insure that this description is a concise statement of the award or modification being authorized. A maximum of 180 characters may be entered.

Enter the name of the awardee if known. A maximum of 30 characters is allowed.

Enter the name of the subsidiary or sub-oiganization of the awardee that will actually pertorm the work. The maximum length is 30 characters. This item may be blank if the awardee is not organized with a division.

Encer the complete mailing address of the place of performance. (Legal address will also be required at time of award for assistance transactions.)

For ... award only, and only if Item 6 is checked ACQUISITION, enter the 4-character code to identify the correct. type of product or service being acquired or supplied.

For new awards only, and only if item 6 is checked ASSISTANCE, enter the correct 6-charecter CFDA number obtained from 
The Catalog of Federal Domestic

Ass istance. An extract of the DOE portion of this catalog appears in APPENDIX B.

14

Proposed Instrument: Cooperative Agreement*

For ASS ISTANCE actions only, check this block if the planned award instrument is to be a cooperative agreement.

Proposed Instrument: Grant*

For ASSISTANCE actions only, check this block if the planned award instrument is to be a grant.

* (For additional details, see DOE Order 4600.1A "Financial Ass istance Procedures Manual.")

OST I Deliverable

Enter the appropriate 2-character of fice of Scientific and Technical Information (OSTI) deliverable code from the $l$ ist conta ined in APPENDIX $C$.

If the award is to be an order under a $D O E$ Master Award BIN, or a delivery order under a GSA schedule or similar contract, enter the schedule or master contract number here.

Enter the date that award of the action being authorized is desired.

Unsolicited Proposal Number

Enter the 10-character unsolicited proposal number, as applicable.

21 Project Number

Enter project number (maximum of 20 characters) assigned by the initiating of fice. 


\section{EINANCIAL DATA}

\section{PROCEDURE}

Enter :he single-character code which indicates whether Government property is involved. If Government property is involved (Code F, B, or P), at tach details to the PR. Code F (Furnished) indicates that the Government is to furnish property to the awardee. Code P (Purchased) indicates that the awardee is to purchase property on behalf of the Government. In both cases, the title to the property remains with the Government at the end of the award. Code $B$ (Both) indicates that property will be furniohed and purchased.

For grants and cooperative agreements, do not indicate that property is purchased or furnished unless title to the property rests with the Government.

For a new award, enter the DOE share of the total estimated award value. regardless of the funding commitment amouat. If this is a "nc dollar" PR, enter zero. This field may be left blank only if the action is an incremental funding mod for which the government share was already reported on a previous PR. For a modification, enter the amount of increase or decrease to the current value. PADS will calculate the resultant value. (If this is a PR for a new award, the Government share should include the total estimated cost over the 1 ife of the contract, including all options.)

If this is a cost-shared action, enter the share of the award value which will be paid for by the awardee. If the actinn is not cost-shared, leave blank. If this is a new award, the awardee share of options should be included. For a modification, enter the amount of increase or decrease as in item 23 .

Enter the dollar amount of the total award value. This must be the sum of items 23 and 24. 
ITEM

26

27

28

29

30

31

32

33
IDENT IF ICAT ION

Appropriation Symbol

BGR Number

Dollar Amount

Al lotment

Object Class

AFP

CFA

From Continuation Sheet (DOE F 4200.34)
PROCEDURES

Enter the 12-character appropriation symbol utilized by the Financial Planning system. (Washington of $\mathrm{fice}$ of Procurement Operations actions only.)

Enter the valid Budget and Reporting Number (maximum of 9 characters) for the FY funds comitted by this request. If there are more $B \& R$ numbers than there is space for on this form, use the DOE F 4200.34, Procurement Request Authorization Funding Data Continuation Sheet.

Enter the amount of FY funds committed for each $B \& R$ number specified in item 27.

Enter the 8-character allotment code utilized by the Financial Planning System. (Washington office of Procurement Operations actions only.)

Enlier the 4-character object classification code identified in OMB Circular A12. (washington of fice of Procurement Operations actions only.)

Enter the 2-digit Approved Funding Program code assigned by the budget office to identify a specific organization. (washington Office of Procurement Operations actions only.)

THIS ITEM IS NOT TO BE COMPLETED BY THE INITIATOR. The Certification of Funds Availibility code is an identification number issued and entered by the finance office at each awarding office.

Enter the total amount of current fiscal year funds committed to this action as specified on DOE F 4200.34, i tem 6. Leave this item blank if DOE F 4200.34 was not used. 
Total Funds This PR
PROCEDURES

Enter the beginning and end dates which define the project period of an assistance action.

Enter the total amount of FY funds committed which is the sum of items 28 and 33. Indicate whether these funds are Annual Funds.

When a correction letter PR is used to update $P R$ data previously reported, the dollar fields will be adjusted by the amounts entered in the same fields on the correction letter PR. (See Section 4.1 of th is Handbook)

Enter the beginning and end dates of the period of time for which the funds identified in item 35 are programmed and bud geted.

*Assistance Actions Only.

Enter the name of the person in the initiating office who is authorized to act as the project manager for this action, or who is responsible for initiating the action.

After reviewing the completed $P R$, the project manager must sign the form in the space provided.

Enter the date the project manager signs the PR.

Enter the organizational code identifying the initiating office and subdivision of the project manager. An example of a valid office code is MA-403.2. At a minimum, the major organizational element (e.g., MA) must be entered.

41 FTS Tel ephone Number

Enter th- FTS telephone number of the project manager. 
Indicate whether the funds being committed are or are not Annual funds

42

43

44

45

46

Signature

47

Date

CER'T IFY ING OFFICIAL

48

Name

49

Signature
Signature

Reviewing officials Name

Date

Budget officials Name
Enter the name of the person in the initiating office who has managerial responsibility for all of the programs with in the of fice.

Atter reviewing the completed PR, the program reviewing official must $s$ ign the form in the space provided.

Enter the date the program reviewing official signs the PR.

Enter the name of the person in the initiating office who is responsible for maintaining the office's fiscal records, and serves as the control officer for procurement requests.

After reviewing the completed $P R$, the program office budget official indicates that funds have been programmed for this action by signing the $P R$ in the space provided.

Enter the date the program office budget ofticial signs the PR.

Enter the name of the responsible person formally designated, such as a finance and accounting officer, who is authorized to certity that funds are available.

After reviewing the PR prepared by the initiating office, the certifying official certifies the availability of funds by signing the PR. 
ITEM

50

51
IDENT IF ICAT ION

Date

Initiating of fice/ Local Office use
PROCEDURES

Enter the date the certifying of ficial signs the PR.

To be used for any messages or instructions with in the initiating office or field organization.

NOTE: Items 45 through 50 are only required for funding actions. 
3. DETAILED INSTRUCT IONS FOR COMPLETING DOE F 4200.34 PROCUREMENT REQUEST AUTHOR IZAT ION FUNDING DATA CONTINUATION SHEET.

ITEM IDENTIFICATION

$1 \quad$ PR Number

2

Change/Correction to a PR in Progress

3

PR Correction Let ter

4
$B \& R$ Number

Dollar Amount

Allotment
Enter the identical PF Number that was entered in Item 3 on the Procurement. Request form DOE F 4200.33 which this continuation sheet is accompanying.

Check the block marked "YES" if this is a change or correction to a PR which has been forwarded to Procurement and is presently in process. Check the block marked "NO" if this is the initial PR for either a new award or a modification to an existing award. The block checked here must be identical to the block checked in $i$ tem 4 on the Procurement Request form DOE F 4200.33 which this continuation sheet is ac companying.

If this is a change or correction action as defined in Item 2, enter an alphabetic character. Start with " $A$ " and continue through the alphabet as additional changes occur. The alphabetic letter entered here must be identical to the one entered in Item 5 of the Procurement Request DOE F 4200.33 which this continuation sheet is ac company ing.

Appropriation Symbol. Enter the 12-character appropriation symbol utilized by the Financial Planning System. (washington Office of Procurement operations actions only.)

Enter the valid Budget and Reporting Number (maximum of 9 characters) for the FY funds comitted by this request.

Enter the amount of funds committed for each $B \& R$ number specified in item 5 .

Enter the 8-character allotment code utilized by the Financial Planning system. (Washington of fice of Procurement Operations actions only.) 
8

Object Class

9

AFP

10

CEA
PROCEDURES

Enter the 4-character object classification code identified in $O M B$ Circular A12. (washington of fice of Procurement Operations actions only.)

Enter the 2-digi $L$ Approved Funding Program code assigned by the budget office to identify a specific organization. (Washington of $\mathrm{fice}$ of Procurement Operations actions only.)

THIS IS NOT TO BE COMPLETED BY THE INITIATOR. The Certification of Funds Availability code is an identification number issued and entered by the finance office at each awarding office. 


\section{ADDITIONAL INSTRUCTIONS FOR PROCESSING PROCUREMENT REQUESTS}

This section is designed to give the program initiator a basic idea of the actions that must be performed for various types of procurement processing. It does not go into a tull, detailed explanation of each process as that process relates to awarding of fice responsibilities.

\subsection{How to Change or Correct a PR}

A. This procedure has been established to enable a user to change the data on a PR, DOE F 4200.33, which has already been forwarded to procurement and is still in process. The instructions are as follows:

1. Item 非, Change/Correction to a PR in Process, must be checked "YES", and the Correction Letter used in Item 非 5 must be the next unused letter in alphabetic order.

2. Items 1 through 9 must be completed for every change action.

3. Non-dollar fields. With the exception of the PR Number (which cannot be changed using this procedure) data entered will replace (overlay) the data previously entered in a specific field. Fields which are to rema in as originally entered should be left blank. An asterisk "*" in the first position of the following fields will remove the data which was previously entered, leaving that element in the data base blank:

Name, Item 10

Division, Item 10a

Unsolicited Proposal Number, Item 20

Project Number, I.tem 21

4. Dollar fields. Changes to dollar fields on the PR will adjust the dollars already entered in the database by the amount entered. Due to the interrelational edits between the dollar fields, a change made to any of the four dollar fields (listed below) requires entry in all four fields. Enter only adjustment amounts.

If a dollar field is to rema in unchanged in the database, a zero must be entered into this dollar field on the correction PR.

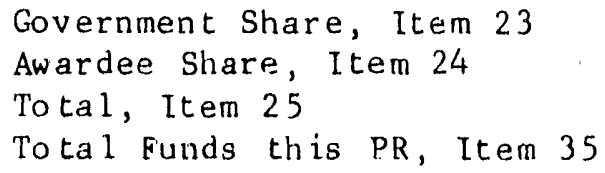

Although $B \& R$ numbers from the $P R$ are no longer entered into PADS ( $B \& R$ numbers are entered at $t i m e$ of award on the IPAR form), PR corrections must still be issued to reflect $B \& R$ changes for finance and file purposes. To complete the PR form to indicate a change in $a B \& R$ number, enter the $B \& R$ number to be deleted and the associated dollars in parentheses along with the new $B \& R$ number with $i$ ts associated dollars. 
B. The following instructions should be used to change or correct DOE F 4200.34, Procurement Request - Authorization Funding Data Continuation Sheet. Since the data is identical to that contained on the PR form, the instructions are similar to those for the PR. Remember that a "correction" Continuation Sheet. must always be accompanied by a "correction" PR. A correction to a Continuation Sheet may never be processed by itself.

1. Item 2 must be checked "YES", and the Correction Letter used in Item 3 must be identical to the one used on Item 5 of the PR form.

2. Non-dollar fields. Items 4 and 7 through 10 should be considered as non-dollar fields. Since they are not stored in the PADS dita base, simply filling in the new value will suffice to replace the old one.

3. Dollar fields. (See A.4. above)

\subsection{Carryover PR Processing}

PR's which do rot get awarded within the fiscal year in which they are ini' iated may be carried over to the next fiscal year in the PADS data base. In order for this carryover process to occur, the following steps must be performed:

\section{Awarding of fice}

1. Indicates to PADS each PR which is a candidate to be carried over.

2. Requests report 非697 which produces machine generated, partially completed "correction" PR forms, with detailed instructions for their completion, for each carryover candidate.

3. Forwards the "correction" PR forms to the program offices which initiated them. 


\section{Program of fice}

1. Completes the machine-generated "correction" PR forms in accordance with the altached instructions to either recertify the funds in the new fiscal year or cancel the request.

2. Returns the completed PR forms to the awarding office which generated them.

From this point on, standard processing of the PR should occur.

NOTE: For all PR's being carried over, the system automatically adjusts the fiscal year designators to reflect the new fiscal year, and changes the first digit of the Amendment Number in the $P R$ number to 8 or 9 . If the newly created number is already in use, the Amendment Number is increased by 1 until an unused number is located.

Al1 numbers $.001-.499$ convert to 800 series

Al1 numbers .501-.699 convert to 900 series

A11.000 numbers rema in unchanged

\subsection{Multiple PR Processing}

Most of the work involved in splitting a PR into a multiple of PR's, each to be awarded separately, is done by the awarding office. The initiating office's one responsibility is to insure that the desire to split the PR is indicated when the $P R$ is forwarded to the awarding office for action.

\subsection{Transfer Procedures}

Authorization for an awarding office to perform a transfer must come from the initiating office responsible for the award being transferred.

1. Authorization to transfer a new $P R$, for which the basic contract has not yet been awarded, should be in the form of a "change/correction" $P R$ to the PR being transferred. The office to which the PR is to be transferred must be specified in the Description of Wcrk (Item 9). Project Manager/Initiator and Program Reviewing official daia (Items 37 through 44 ) must also be included.

2. Authorization to transfer an entire acquisition or assistance record should be in the form of a modification (a PR with Amendment Number .001 or greater). The office to which the instrument is to be transferred must be specified in the Description of Work. 
CODE

01.

02

03

04

05

06

07

08

09

11

12

13

15

16

17

18

19

20

21

22

32

33

34

39

41

42

43

44

45

46

47

48

65

70

75

79

85

91

96

\section{DESCR I PTION}

Washington Office of Procurement Operations Chicago Operations Otfice

San Francisco Operations Office

Albuquerque Operations office

Oak Ridge Operations Office

Richland Operations of fice

Idaho Operations of $f i c e$

Nevada Operations Office

Savannah River Operations of fice

Pittsburgh Naval Reactors Office

Schenectady Naval Reactors Office

Grand Junction Office

Clinch River Breeder Reactor Plant Project Office

Portsmouth Enrichment Office

Environmenta 1 Measurements Laboxatory.

Grand Forks Project of fice

Bartlesville Project office

Laramie Project office

Morgantown Energy Technology Center

Pittsburgh Energy Technology anter

Los Alamos Area of fice

Kansas City Area Office

Rocky Flats Area Office

Federal Energy Regulatory Commission

Boston Support office

New York Support Office

Philadelphia Support office

Atlanta Support office

Chicago Support office

Dallas Support office

Kansas City Support office

Denver Support of fice

western Area Power Administration

Southeastern Power Administration

Southwestern Power Administration

Bonneville Power Administration

Alaska Power Administration

Naval Petroleum and 0i.1 Shale Reserves

Strategic Petroleum Reserve Project Management of fice

Salt Repository Project Office 
CATALOG OF FEDERAL DOMEST IC ASS ISTANCE (CFDA) CONES

CODE

$\star 81.002$

81.003

81.004

$* 81.007$

81.011

81.022

$* 81.023$

81.028

$\star 81.029$

$\star 81.033$

$* 81.035$

81.036

$* 81.037$

$\star 81.038$

81.039

$* 81.040$

81.041

81.042

$* 81.043$

$* 81.044$

$* 81.045$

$\star 81.046$

81.047

81.048

81.049

81.050

$* 81.051$

81.052

$* 81.053$

$* 81.054$

$* 81.055$

$* 81.056$

81.057

$* 81.058$

$* 81.059$

$\times 81.050$

$\times 81.061$

$\star 81.062$

\section{DES CR I PT ION}

MOTION PI CTURE FILM LIBRARIES

GRANT ING OF PATENT LICENSES

UNIVERS ITY-LABORATORY COOPERAT IVE PROGRAM

TEACHER DEVELOPMENT PROJECTS IN ENERGY

UNIVERS ITY REACTOR SHARING FUEL ASSISTANCE

USED ENERGY-RELATED LABOR F TORY EQUIPMENT GRANTS

INFORMATION SERVI CES - EXHIBITS, ETC

RAD IOLOG ICAL EMERGENCY ASS ISTANCE

URANIUM INDUSTRY SEM INARS

CIT IZENS ' WORKS HOPS

$R \& D$ IN ENERGY OONSERVATION

ENERGY-RELATED INVENTIONS

$R \& D$ - FISSION, FOSSIL, SOLAR, GEOTHERMAL

ENERGY INFORMAT ION ADMIN ISTRAT ION CLEAR INGHOUSE

NAT IONAL ENERGY INFORMATION CENTER

GRANTS FOR OFFICES OF CONSUMER SERVICES

STATE ENERGY CONSERVATION

WEATHER IZATION ASS ISTANCE FOR LOW-INCOME PERSONS

SUPPLEMENTAL STATE ENERGY CONSERVATION

PUBL IC EDUCATION IN ENERGY.

SPECIAL STUDIES \& PROJECTS ENERGY EDUCATION AND

TRA IN ING

ENVIRCNMEIITAL RESEARCH AND IMPACT ASSESSMENT

PRE-FRESHMAN ENGINEER ING

PR IORITIES \& ALLOCATIONS FOR ENERGY PROGRAMS

AND PROJECTS

BASIC ENERGY SCIENCES, HIGH ENERGY AND NUCLEAR

PHYSICS, MAGNETIC FUSION ENERGY, HEALTH \&

ENVII IMENTAL RESEARCH, PROGRAM ANALYSIS, AND

FIEL: JPERAT IONS MANAGEMENT

ENEKGY EXTENS ION SERVICE

APPROPRIATE ENERGY TECHNOLOGY

ENERGY CONSERVATION FOR INST ITUT IONAL BUILDINGS

PUBLIC UTILITIES REGULATORY INNOVATIVE RATE: SUPPOR'T

PUBLIC UTILITIES REGULATORY SUPPORT

SMALL HYDROELECTRIC POWER PROJECT FEASIBILITY STUDIES

COAL LOAN GUARANTEES

UNIVERS ITY COAL RESEARCH

GEOTHERMAL LOAN GUARANTEES

CLEARINGHOUSE FOR COMMUNITY ENERGY EFFICIENCY

LLECTRIC \& HYBRID VEHICLE LOAN GUARANTEE PROGRAM

OIL SHALE STATE GRANT PROGRAM

NAT IONAL CLUBS, ORGANIZATIONS, \& ASSOCIATION ENERGY CONSERVAT ION 
APPENDIX B

( Cont'd)

CATALOG OF FEDERAL DOMESTIC ASS ISTANCE (CFDA) CODES

CODE

$$
\begin{array}{r}
81.063 \\
81.064 \\
81.065 \\
* 81.066 \\
* 81.067 \\
* 81.068 \\
* 81.069 \\
* 81.070 \\
* 81.071 \\
* 81.072 \\
* 81.073 \\
* 81.074 \\
* 81.075 \\
* 81.076 \\
81.077 \\
81.078 \\
81.079 \\
81.080 \\
81.081 \\
81.082 \\
\\
81.083 \\
81.084 \\
81.085 \\
81.086 \\
81.087 \\
81.088 \\
81.089 \\
* 81.090 \\
81.091 \\
81.092 \\
81.093 \\
81.094 \\
81.095
\end{array}
$$

DESCR IPTION

OFFICE OF MINORITY ECONOMIC IMPACT LOANS

OFFICE OF SCIENT IFIC \& TECHNICAL INFORMATION NUCLEAR WASTE DISPOSAL SITING

AMEKICAN INDIAN ENERGY PRODUCTION \& EFFICIENCY TECHNICAL ASS ISTANCE FOR LOCAL AND TRIBAL GOVERNMENTS BIOMASS LOAN GUARANTEES GASOL INE RATIONING - STATE PRE-IMPLEMENTATION ENERGY AUDITOR TRAINING \& CERTIFICATION EMERGENCY ENERGY CONSERVATION ACT PLANS $R \& D$ IN ENERGY CONSERVATION RETROFIT DELIVERY $R \& D$ - GEOTHERMAL TECHNOLOGIES ALCOHOL FUELS PROGRAM LOAN GUARANTEES ENERGY GRADUATE TRAINEESHIP PROGRAM IND IAN ENERGY RESOURCES UNIVERS ITY RESEARCH INS TRUMENTAT ION INDUSTR LAL ENERGY CONSERVA'TION BIOFUELS \& MUNICIPAL WASTE TECHNOLOGY ENERGY POLICY, PLANN ING AND DEVELOPMENT ENERGY TASK FORCE FOR THE URBAN CONSOR'TIUM MANAGEMENT AND TECHN I CAL ASS ISTANCE FOR MINOR ITY BUS INESS ENTERPR ISES

MINORITY EDUCATIONAL INSTITUTION RESEARCH TRAVEL FUNDS MINORITY HONORS VOCA'T IONAL TRAINING NAT IONAL MINOR ITY ENERGY INFORMATION CLEARINGHOUSE CONSERVATION RESEARCH AND DEVELOPMEN'T RENEWABLE ENERGY RESEARCH \& DEVELOPMENT INTERNATIONAL AFFAIRS \& ENERGY EMERGENCIES FOSSIL ENERGY RESEARCH AND DEVEILOPMENT STATE HEATING OIL GRANTS SOCIOECONOMIC \& DEMOGRAPHIC RESEARCH, DATA \& OTHER INFORMA'TION REMED IAL ACT ION AND NUCLEAR WASTE TECHNOLOGI NUCLEAR ENERGY POLICY, PLANNING \& DEVELOPMENT MINORITY EDUCATIONAL INSTITUTION ASSISTANCE NUCLEAR ENERGY, REACTOR SYSTEMS, DEVELOPMENT \& TECHNOLOGY 
APPENDIX B

( Cont'd)

81.096
81.097
$\star 81.501$
$\star 81.502$
$\star 81.503$
$\star 81.504$
$\star 81.505$
$\star 81.506$
$\star 81.507$
$\star 81.508$
$\star 81.509$
$* 81.510$
$\star 81.511$
$\star 81.801$
INNOVATIVE CLEAN COAL TECHNOLOGY

SCIENCE AND ENGINEERING RESEARCH SEMESTER

APPROPRIATE TECHNOLOGY SMALL LOAN PROGRAM

MISCELLANEOUS FEDERAL ASSISTANCE ACTIOINS

ALTERNATIVE FUELS PROGRAM

NATURAL GAS FROM COAL BEDS \& DEVONIAN SHALE

SMALL HYDROELECTRIC LOAN PROJECT PROGRAM

EMERGEHCY BUIIDING TEMPERATURE RESTRICT IONS PROGRAM INVENTORY OF SMALL DAMS PROGRAM

NUCLEAR WASTE TERM INAL STORAGE PROGRAM

LOW COST / NO COST RESIDENT IAL ENERGY CONSERVA'TION

ALCOHOL FUELS TECHNOLOGY GRANT PROGRAM

TECHNOJOGY TRANSFER ACT IVIT' IES

STRATEGIC PETROLEUM RESERVE

* Indicates code not valid for new awards 
OFFICE OF SCIEN'T IFIC AND TECHNICAL INFORMA'T ION (OS'TI) DELIVERABLE CODES

CODE

\section{AA}

$A D$

$\mathrm{AH}$

AK

AL

AM

AN

$\mathrm{AU}$

AZ

$B D$

$B E$

$B C$

BI

BJ

$B M$

BO

BV

BW

$\mathrm{CD}$

CF

CG

$\mathrm{CH}$

$\mathrm{CM}$

$\mathrm{CN}$

$\mathrm{CQ}$

CT

$\mathrm{CU}$

$\mathrm{CW}$

DD

MO

$Y Y$

YZ

\section{DES CR I PT ION}

Annual

Final.

Quarterly Plus Annual

Quarterly Plus Final

Quarterly

Semiannua 1

Interim or Topical plus final

Conference Proceedings

No Technical Deliverable Required

Monthly Plus Final

Monthly Plus Quarterly Plus Annual Plus Final

Monthly

Special (Books, Films, etc.)

Monthly Plus Annual

Semiannual Plus Final

Semiannual Plus Annual Plus Final

Annual Plus Final

Quarterly Plus Semiannual Plus Annual

One Interim or Topical

Monthly Plus Quarterly Plus Final

Bimonthly Plus Final

Monthly Plus Annual Plus Final

Two Interim or Topical

Three Interim or Topical

Quarterly Plus Annual Plus Final

Master Contract (No Reports Required)

Technical Del iverables but no Technical Reports

Terminated or Cancelled

Other

Requirement not specified (M\&O Contractors, etc.)

Computer Software

Computer Software Plus Final 

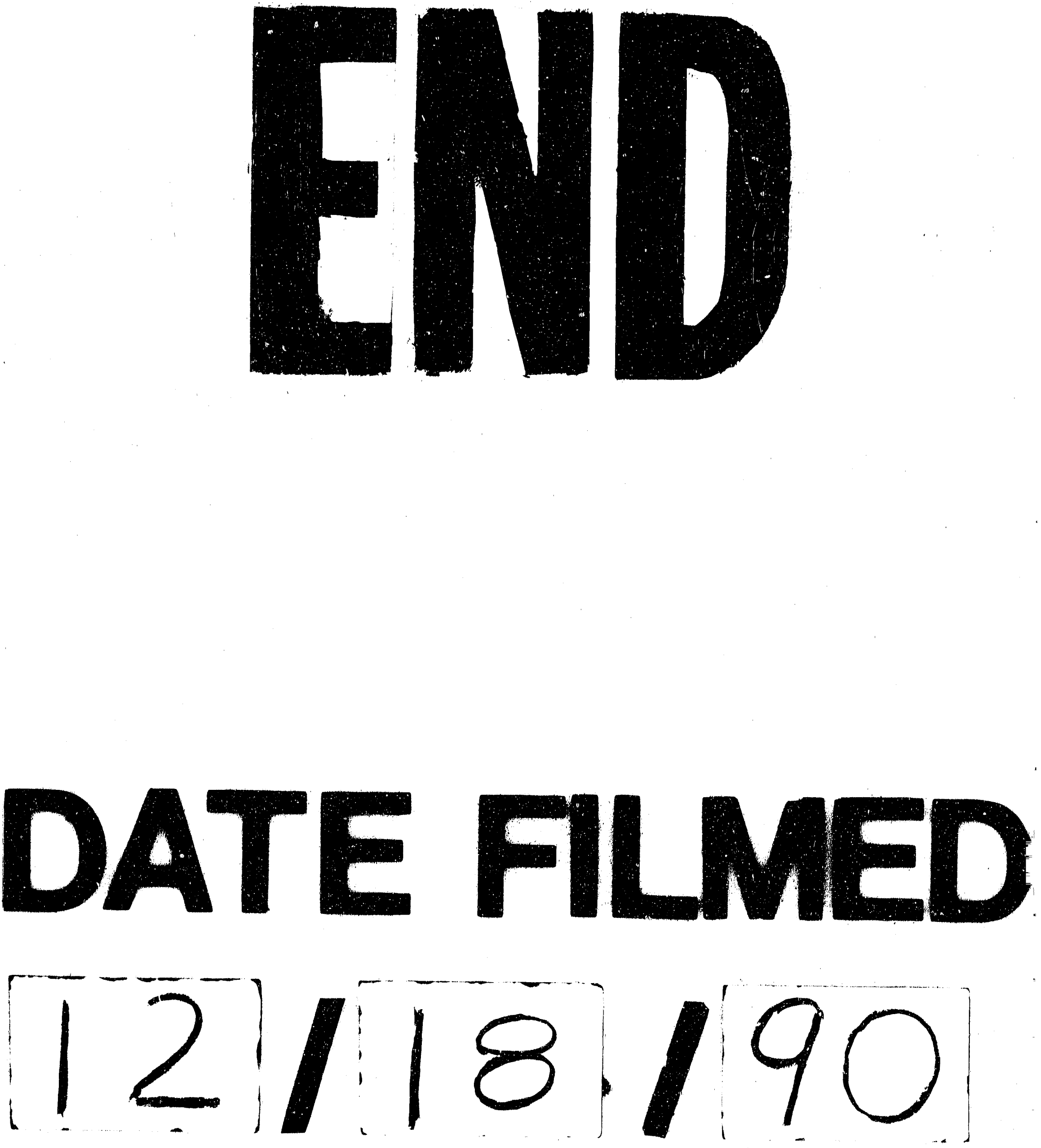
